\title{
Microencapsulação de Lactobacillus Acidophilus: Curva de Crescimento e Influência da Ativação da Cultura Sobre A Viabilidade Celular
}

\author{
Leidiane Andreia Acordi Menezes (I), Deisy Alessandra Drunkler (I) \\ (I) UTFPR-MD - Universidade Tecnológica Federal do Paraná (Av. Brasil, 4232 - Parque \\ Independência, Medianeira, Paraná, Brasil.)
}

\section{Resumo}

A sobrevivência de micro-organismos encapsulados por atomização está associada, entre outros fatores, a condição na qual se encontra a cultura no momento da secagem. $\mathrm{O}$ trabalho visou verificar se a atomização da cultura na fase estacionária favoreceria sua viabilidade. Realizou-se a determinação da curva de crescimento de L. acidophilus, a fim de estabelecer qual tempo necessário para que a cultura atingisse a fase estacionária, referida como a que melhor preserva a viabilidade celular. A cultura $(1 \% \mathrm{~m} / \mathrm{v})$ foi adicionada ao caldo MRS e incubada em estufa a $37^{\circ} \mathrm{C}$ durante 15 horas e a concentração bacteriana acompanhada a cada hora, por densidade óptica em espectrofotômetro a $600 \mathrm{~nm}$ e relacionada ao logaritmo da enumeração de células viáveis. Após a definição do tempo necessário para a chegada à fase estacionária, extrato de soja em pó e maltodextrina foram dispersos em água estéril (2:1), até obtenção de três soluções de atomização com concentração de $15 \%(\mathrm{~m} / \mathrm{v})$, em seguida três métodos de preparo de inoculo foram avaliados: 1) ativação da cultura na solução de atomização até a chegada à fase estacionária; 2) ativação da cultura em caldo MRS, recuperação das células na fase estacionária e adição à solução de atomização e 3) adição da cultura não ativada à solução de atomização no momento da secagem. As soluções foram secas em spray dryer (MSD 1.0, Labmaq do Brasil), operado com temperatura de entrada de ar de $85^{\circ} \mathrm{C}$. A redução da viabilidade foi expressa em ciclos log como o valor logarítmico da fração de sobrevivência relativa, considerando-se o número

\footnotetext{
Referência:

Leidiane Andreia Acordi Menezes, Deisy Alessandra Drunkler.Microencapsulação de Lactobacillus Acidophilus: Curva de Crescimento e Influência da Ativação da Cultura Sobre A Viabilidade Celular. In: Anais do 12ㅇ Congresso Latinoamericano de Microbiologia e Higiene de Alimentos - MICROAL 2014 [= Blucher Food Science Proceedings, num.1, vol.1]. São Paulo: Editora Blucher, 2014. DOI 10.5151/foodsci-microal-016
} 
de células viáveis antes e após a atomização. A cultura atingiu a fase estacionária em 12 horas de ativação $(10,41$ log UFC.g-1, DO 0,40) tempo a partir do qual o crescimento foi estabilizado, e, portanto, estabelecido para a ativação da cultura nas soluções de atomização. Houve diferença significativa $(\mathrm{p}$

Palavras-Chave: Encapsulação, Probióticos, Fase de crescimento Agência de Fomento: $\mathrm{CNPq}$ 